\title{
ANALISIS KINERJA KEUANGAN PT TRAKINDO UTAMA, TEMBAGAPURA DIVISION
}

Oleh :

Stella Laura Simba

stellasimba0@gmail.com

Institut Bisnis dan Keuangan Nitro

\begin{abstract}
Abstrak
Penelitian ini berjudul Analisis Kinerja Keuangan Perusahaan PT Trakindo Utama, Tembagapura Division. Penelitian ini bertujuan untuk mengetahui, memprediksidan menganalisis kinerja keuangan dengan menggunakan rasio-rasio keuangan: 1.) Rasio Likuiditas, 2.) Rasio Solvabilitas, 3.) Rasio Profitabilitas, dan 4.) Rasio Aktivitas. Metode analisis yang digunakan dalam penelitian ini yaitu: metode kuantitatif. Adapun desain penelitian yang diperlukan adalah deskriptif komparatif yang bertujuan untuk mengetahui kinerja keuangan peusahaan.
\end{abstract}

Kata kunci: Kinerja Keuangan, Rasio keuangan)

\section{PENDAHULUAN}

\section{Latar Belakang}

Dewasa ini kondisi perekonomian Indonesia semakin kompetitif. Hal ini menjadi perhatian khusus bagi pemerintah dan pelaku usaha untuk lebih kreatif dalam menciptakan iklim usaha. Salah satu upaya yang dilakukan untuk menghadapi kondisi ini pengusaha harus dapat meningkatkan efektifitas dan efisiensi perusahaan. Salah satunya caranya adalah dengan memanfaatkan perusahaan yang bergerak di bidang penyedia jasa atau penyedia tenaga kerja, seperti PT. Trakindo Utama.

PT Trakindo Utama merupakan salah satu perusahaan perantara yang menjual alat -alat berat milik perusahaan Amerika yaitu Caterpillar (CAT), dimana PT 
Trakindo Utama memiliki 4 penjualan rutin setiap bulannya. Penjualan tersebut adalah penjualan mesin, penjualan sparepart, penjualan unit dan penjualan jasa. Keempat penjualan tersebut setiap bulannya memiliki target penjualan yang meningkat terus-menerus, perusahaan mengharapkan seorang karyawan untuk bias tetap loyal, agar dapat bekerja dengan baik.

Menurut Kurniawan dalam Daga (2019) menyatakan bahwa factor-faktor yang mempengaruhi loyalitas karyawan yaitu :

a. Gaya kepemimpinan

b. Tipe gaya kepemimpinan

c. Stress kerja

d. Keadilan dan kompensasi

e. Lingkungan kerja

Tentunya kinerja keuangan sangat berperan aktif dalam pencapaian tujuan tersebut.

Adapun para ahli tentang kinerja keuangan salah satunya adalah Hery (2015) Kinerja keuangan merupakan suatu usaha formal untuk mengevaluasi efisiensi dan efektivitas perusahaan dalam menghasilkan laba dan posisi kas tertentu. Dengan pengukuran kinerja keuangan, dapat dilihat prospek pertumbuhan dan perkembangan keuangan perusahaan. Perusahaan dikatakan berhasil apabila perusahaan telah mencapai suatu kinerja tertentu yang telah ditetapkan. "Perusahaan yang sehat nantinya akan dapat memberikan laba bagi para pemilik modal, perusahaan yang sehat juga dapat membayar hutang dengan tepat waktu". Selain itu, kinerja keuangan dari suatu perusahaan yang telah dicapai dalam satu tahun atau satu periode waktu, adalah gambaran sehat atau tidaknya keadaan suatu perusahaan. Fidhayatin (Aringga, 2017)

Pengukuran kinerja perusahaan diperlukan untuk menentukan keberhasilan dalam mencapai tujuan tersebut dan sebagai evaluasi serta perencanaan masa depan perusahaan. Dengan pengukuran kinerja terhadap perusahaan, maka perusahaan dapat mengetahui kinerja perusahaan yang sebenarnya, sehingga perusahaan dapat bertahan dan tidak tersingkir dalam persaingan yang semakin kuat dan ketat dalam dunia bisnis. Salah satunya dilakukan oleh PT. Trakindo Utama, Tembagapura Division. 
Pengukuran kinerja pada perusahaan menggunakan laporan keuangan sebagai penyedia dasar dalam penilaian kinerja internal dan eksternal perusahaan. Kinerja internal ini seperti profitabilitas dan likuiditas dapat diperoleh dengan menggunakan analisis perbandingan antara kinerja periode yang lalu dengan periode saai ini dalam bentuk analisis rasio. Sementara itu, kinerja eksternal seperti penilaian pasar dapat dilakukan dengan analisis perbandingan antara kinerja perusahaan dengan standar industrial atau market standing dari saham perusahaan tersebut.

\section{Tujuan Penulisan}

Adapun tujuan penelitian ini adalah untuk mengetahui dan menganalisis kinerja keuangan PT Trakindo Utama, Tembagapura Division.

\section{Manfaat Penulisan}

a) Bagi Penulis

Untuk mengetahui dan menerapkan ilmu yang diperoleh selama perkuliahan serta menambah pengetahuan penulis.

b) Bagi Pembaca

Untuk menambah wawasan pembaca tentang kinerja keuangan PT Trakindo Utama, Tembagapura Division.

\section{KAJIAN PUSTAKA}

\section{Kinerja Keuangan}

\section{a. Pengertian Kinerja Keuangan}

Menurut Fahmi (2011:2) kinerja keuangan adalah suatu analisis yang dilakukan untuk melihat sejauh mana suatu perusahaan telah melaksanakan dengan menggunakan aturan-aturan pelaksanaan keuangan secara baik dan benar. Kinerja perusahaan merupakan suatu gambaran tentang kondisi keuangan suatu perusahaan yang dianalisis dengan alat-alat analisis keuangan, sehingga dapat diketahui mengenai baik buruknya keadaan keuangan suatu perusahaan yang mencerminkan prestasi kerja dalam periode tertentu. Hal ini sangat penting agar sumber daya digunakan secara optimal dalam menghadapi perubahan lingkungan.

Sedangkan menurut (Hery:2015) kinerja keuangan merupakan suatu usaha formal untuk mengevaluasi efisiensi dan efektivitas perusahaan dalam 
menghasilkan laba dan posisi kas tertentu. Dengan pengukuran kinerja keuangan, dapat dilihat prospek pertumbuhan dan perkembangan keuangan perusahaan. Perusahaan dikatakan berhasil apabila perusahaan telah mencapai suatu kinerja tertentu yang telah ditetapkan. perusahaan yang sehat nantinya akan dapat memberikan laba bagipara pemilik modal, perusahaan yang sehat juga dapat membayar hutang dengan tepat waktu". Selain itu, kinerja keaunagan dari suatu perusahaan yang telah dicapai dalam satu tahunatau satu periode waktu, adalah gambaran sehat atau tidaknya keadaan suatu perusahaan (Fidhayatin, 2012:205).

\section{b. Tahapan-Tahapan Dalam Menganalisis Kinerja Keuangan}

Menurut Fahmi (2011:2) penilaian kinerja setiap perusahaan adalah berbeda-beda karena itu tergantung kepada ruang lingkup bisnis yang dijalankannya. Jika perusahaan tersebut bergerak pada sektor bisnis pertambangan maka itu berbeda dengan perusahaan yang bergerak pada bisnis pertanian serta perikanan. Maka begitu juga pada perusahaan dengan sektor keuangan. Ada 5 (lima) tahapan dalam menganalisis kinerja keuangan suatu perusahaan secara umum, yaitu

1. Melakukan review terhadap data laporan keuangan

2. Melakukan perhitungan

3. Melakukan perbandingan terhadap hasil hitungan yang telah diperoleh

4. Melakukan penafsiran (interpretation) terhadap berbagai permasalahan yang ditemukan

5. Mencari dan memberikan pemecahan masalah (solution) terhadap permasalahan yang ditemukan

5 (lima) tahapan dalam menganalisis kinerja keuangan tersebut dapat dijelaskan sebagai berikut :

1. Melakukan review terhadap data laporan keuangan

Review di sini dilakukan dengan tujuan agar laporan keuangan yang sudah di buat tersebut sesuai dengan penerapan kaidah-kaidah yang berlaku umum dalam dunia akutansi, sehingga dengan demikian hasil laporan keuangan tersebut dapat dipertanggungjawabkan.

2. Melakukan perhitungan 
Penerapan metode perhitungan di sini adalah disesuaikan dengan kondisi dan permasalahan yang sedang dilakukan sehingga hasil dari perhitungan tersebut akan memberikan suatu kesimpulan sesuai dengan analisis yang diinginkan.

3. Melakukan perbandingan terhadap hasil hitungan yang telah diperoleh

Dari hasil hitungan yang sesuai diperoleh tersebut kemudian dilakukan perbandingan dengan hasil hitungan dari berbagai perusahaan lainnya.

Metode yang paling umum dipergunakan untuk perbandingan ini ada dua yaitu :

a. Time series analysis, yaitu membandingkan secara antar waktu atau antara periode, dengan tujuan itu nantinya akan terlihat secara grafik.

b. Cross sectional approach, yaitu melakukan perbandingan terhadap hasil hitungan rasio-rasio yang telah dilakukan antara satu perusahaan dan perusahaan lainnya dalam ruang lingkup yang sejenis yang dilakukan secara bersamaan.

4. Melakukan penafsiran (interpretation) terhadap berbagai permasalahan yang ditemukan

Penafsiran untuk melihat apa-apa saja permasalahan dan kendala-kendala yang di alami perusahaan tersebut.

5. Mencari dan memberikan pemecahan masalah (solution) terhadap permasalahan yang ditemukan

Pada tahap terakhir ini setelah ditemukan berbagai permasalahan yang dihadapi maka dicarikan solusi guna memberikan suatu input atau masukan agar apa yang menjadi kendala dan hambatan selama ini dapat terselesaikan.

\section{Laporan Keuangan}

\section{a. Pengertian Laporan Keuangan}

Menurut Hery (2012:2) laporan keuangan adalah hasil dari proses akuntansi yang dapat digunakan sebagai alat untuk mengkomunikasikan data keuangan atau aktivitas perusahaan kepada pihak-pihak yang berkepentingan. 
Dengan kata lain sebagai alat informasi yang menghubungkan perusahaan dengan pihak-pihak yang berkepentingan, yang menunjukkan kondisi kesehatan keuangan perusahaan dan kinerja perusahaan.

Sedangkan menurut Kasmir (2015:7) Laporan keuangan adalah laporan yang menunjukkan kondisi keuangan perusahaan pada saat ini atau dalam suatu periode tertentu.

Menurut Fahmi (2011) laporan keuangan merupakan suatu informasi yang menggambarkan kondisi suatu perusahaan, dimana selanjutnya itu akan menjadi suatu informasi yang menggambarkan tentang kinerja suatu perusahaan.

Laporan keuangan juga merupakan hasil akhir dari suatu proses pencatatan yang merupakan suatu ringkasan dari transaksi-transaksi keuangan yang terjadi selama tahun buku yang bersangkutan. Laporan keuangan dibuat oleh manajemen dengan tujuan untuk membebaskan diri dari tanggung jawab yang dibebankan kepadanya oleh pemilik perusahaan. Untuk dapat memperoleh gambaran keuangan perusahaan dengan jelas maka dapat dilakukan dengan mengadakan analisa interprestasi terhadap data keuangan suatu perusahaan yang tercermin dalam laporan keuangan.

Berdasarkan pengertian di atas dapat disimpulkan bahwa laporan keuangan suatu perusahaan merupakan hasil akhir dari proses akuntansi, yang disusun dengan maksud untuk memberikan gambaran atau laporan tentang perkembangan usaha secara periodik yang berkenaan dengan situasi investasi di dalam perusahaan serta hasil usaha selama periode akuntansi yang bersangkutan.

\section{b. Tujuan Laporan Keuangan}

Menurut Fahmi (2011) tujuan laporan keuangan adalah memberikan informasi keuangan yang mencakup perubahan dari unsur-unsur laporan keuangan yang ditujukan kepada pihak-pihak lain yang berkepentingan dalam menilai kinerja keuangan terhadap perusahaan di samping pihak manajemen perusahaan.

Sedangkan menurut Kasmir (2014:10), tujuan dari pembuatan laporan keuangan terdiri atas tujuh tujuan, antara lain: 
1) Menyajikan informasi mengenai jenis serta jumlah aktiva (harta) yang dipunyai perusahaan pada masa sekarang.

2) Menyajikan informasi mengenai jenis serta jumlah kewajiban dan juga modal yang dipunyai perusahaan pada waktu ini.

3) Menyajikan informasi mengenai jenis serta jumlah pendapatan yang didapatkan dalam suatu periode tertentu.

4) Menyajikan informasi mengenai jumlah biaya serta jenis biaya yang dikeluarkan oleh perusahaan dalam suatu periode tertentu.

5) Menyajikan informasi mengenai berbagai perubahan yang berlangsung kepada aktiva, pasiva, serta modal perusahaan.

6) Menyajikan informasi mengenai kinerja manajemen perusahaan dalam suatu perode.

7) Menyajikan informasi mengenai berbagai catatan atas laporan keuangan.

Dari beberapa tujuan di atas dapat disimpulkan bahwa tujuan laporan keuangan adalah memberikan informasi yang berguna untuk memberikan informasi keuangan, menyajikan informasi mengenai berbagai perubahan yang berlangsung kepada aktiva, pasiva, serta modal perusahaan serta memberikan informasi mengenai berbagai perubahan yang berlangsung kepasa aktiva, pasiva, serta modal perusahaan.

\section{c. Jenis Laporan Keuangan}

Menurut Kasmir (2014:9), ada lima jenis laporan keuangan, yaitu :

1. Balance Sheet (Neraca)

Balance Sheet(neraca) merupakan laporan yang menunjukan posisi keuangan perusahaan pada tanggal tertentu. Arti dari posisi keuangan dimaksudkan adalah posisi jumlah dan jenis aktiva (harta) dan passiva (kewajiban dan ekuitas) suatu perusahaan.

2. Income Statement (Laporan Laba Rugi)

Income Statement (Laporan laba rugi) merupakan laporan keuangan yang menggambarkan hasil usaha perusahaan dalam satu periode tertentu. Dalam laporan laba rugi ini tergambar jumlah pendapatan dan sumber-sumber pendapatan yang diperoleh. Kemudian 
juga tergambar jumlah biaya dan jenis jenis yang dikeluarkan selama periode tertentu.

3. Laporan Perubahan Modal

Laporan perubahan modal merupakan laporan yang berisi jumlah dan jenis modal yang dimiliki pada saat ini. Kenudian, laporan ini juga menjelaskan perubahan modal dan sebab-sebab terjadinya perubahan modal di perusahaan.

4. Laporan Arus Kas

Laporan arus kas merupakan laporan yang menunjukan arus kas masuk dan kas keluar perusahaan. Arus kas masuk merupakan pendaatan atau pinjaman dari pihak lain, sedangkan arus kas keluar merupakan biaya-biaya yang telah dikeluarkan perusahaan. Baik arus kas masuk maupun arus kas keluar dibuat untuk periode tertentu.

5. Laporan Catatan Atas Laporan Keuangan

Laporan catatan atas laporan keuangan merupakan laporan yang dibuat berkaitan dengan laporan keuangan yang disajikan. Laporan ini memberikan informasi tentang penjelasan yang dianggap perlu atas laporan keuangan yang ada sehingga menjadi jelas sebab penyebabnya. Tujuannya adalah agar pengguna laporan keuangan dapat mamahami jelas data yang disajikan.

\section{d. Penggunaan Laporan Keuangan}

Menurut Harahap (2011:7-9), pengguna laporan keuangan antara lain sebagai berikut :

1) Pemilik Perusahaan

Bagi pemilik perusahaan laporan keuangan dimaksudkan untuk:

a. Menilai prestasi atau hasil yang diperoleh manajemen perusahaan

b. Mengetahui hasil deviden yang akan diterima

c. Menilai posisi keuangan perusahaan dan pertumbuhannya

d. Mengetahui nilai saham dan laba perlembar saham

e. Sebagai dasar untuk memprediksi kondisi perusahaan di masa yang akan datang; 
f. Sebagai dasar untuk mempertimbangkan menambah atau mengurangi investasi.

2) Manajemen Perusahaan

Bagi manajemen perusahaan laporan keuangan digunakan untuk:

a. Alat untuk mempertanggung jawabkan pengelolaan kepada pemilik

b. Mengatur tingkat biaya dari setiap kegiatan operasi perusahaan, divisi, bagian segmen tertentu

c. Mengukur tingkat efisiensi dan tingkat keuntungan perusahaan, divisi, bagian atau segmen tertentu

d. Menilai hasil kerja individu yang diberikan tugas dan tanggung jawab

e. Untuk menjadi bahan pertimbangan dalam menentukan perlu tidaknyadiambil kebijakan baru

f. Memenuhi ketentuan dalam UU, peraturan, Anggaran Dasar, Pasar Modal, dan lembaga regulator lainnya.

3) Investor

Bagi Investor perusahaan laporan keuangan digunakan untuk:

a. Menilai kondisi keuangan dan hasil usaha perusahaan

b. Menilai kemungkinan menanamkan dana dalam perusahaan

c. Meniali kemungkinan menambah divestasi (menarik investasi) dari perusahaan

d. Menjadi dasar memprediksi kondisi perusahaan dimasa datang.

4) Kreditor atau Banker

Bagi Kreditor, Banker atau Supplier laporan keuangan digunakan untuk :

a. Menilai kondisi keuangan dan hasil usaha perusahaan dalam jangka pendek maupun dalam jangka panjang

b. Menilai kualitas jaminan kredit / investasi untuk menopang kredit yang akan diberikan 
c. Melihat dan memprediksi prospek keuntungan yang mungkin diperoleh dari perusahaan atau menilai rate of returnperusahaan.

d. Menilai kemampuan likuiditas, solvabilitas, rentabilitas perusahaan sebagai dasar dalam pertimbangan keputusan kredit

e. Menilai sejauh mana perusahaan mengikuti perjanjian kredit yang sudah disepakati.

5) Pemerintah dan Regulator

Bagi Pemerintah dan Regulator laporan keuangan digunakan untuk :

a. Menghitung dan menetapkan jumlah pajak yang harus dibayar

b. Sebagai dasar dalam menetapkan kebijakan-kebijakan baru

c. Menilai apakah perusahaan memerlukan bantuan atau tindakan lain

d. Menilai kepatuhan perusahaan terhadap aturan yang ditetapkan

e. Bagi lembaga pemerintah lainnya bisa menjadi bahan penyusunan data dan statistic.

6) Analisis, Akademis, Pusat Data Bisnis

Para analis, akademis dan juga lembaga-lembaga pengumpulan data bisnis laporan keuangan penting sebagai bahan atau sumber informasi yang akandiolah sehingga menghasilkan informasi yang bermanfaat bagi analisa, ilmu pengetahuan dan komoditi informasi.

\section{Analisis Laporan Keuangan}

\section{a. Pengertin Laporan Keuangan}

Menurut Kasmir (2016:66) analisis laporan keuangan dilakukan untuk mengetahui posisi keuangan perusahaan sehingga akan terlihat apakah perusahaan dapat mencapai target yang telah direncanakan sebelumnya atau tidak. 
Sedangkan menurut Prastowo (2015:50) analisis laporan keuangan merupakan suatu proses yang penuh pertimbangan dalam rangka membantu mengevaluasi posisi keuangan dan hasil operasi perusahaan pada masa sekarang dan masa lalu, dengan tujuan utama untuk menentukan estimasi dan prediksi yang palin mungkin mengenai kondisi dan kinerja perusahaan pada masa mendatang.

Berdasarkan pendapat tersebut dapat dipahami bahwa laporan keuangan sangat berguna dalam melihat kondisi keuangan suatu perusahaan, baik kondisi pada saat ini maupun dijadikan sebagai alat prediksi untuk kondisi di masa yang akan datang (forecast analyzing).

\section{b. Tujuan Laporan keuangan}

Menurut Kasmir (2013:68) tujuan analisis laporan keuangan adalah:

1. Untuk mengetahui posisi keuangan perusahaan dalam satu periode tertentu, baik harta, kewajiban, modal maupun hasil usaha yang telah dicapai untuk beberapa periode.

2. Untuk mengetahui kelemahan-kelemahan apa saja yang menjadi kekurangan perusahaan.

3. Untuk mengetahui kekuatan-kekuatan yang dimiliki perusahaan.

4. Untuk mengetahui langkah-langkah perbaikan apa saja yang perlu dilakukan ke depan yang berkaitan dengan posisi keuangan perusahaan saat ini.

5. Untuk melakukan penilaian kinerja manajemen ke depan apakah perlu penyegaran atau tidak karena sudah dianggap berhasil atau gagal.

6. Dapat juga digunakan sebagai pembanding dengan perusahaan sejenis tentang hasil yang mereka capai.

Sedangkan menurut Sugiono dan Untung (2016:10) kegunaan analisis laporan keuangan adalah:

1. Untuk memberikan informasi yang lebih mendalam terhadap laporan keuangan itu sendiri

2. Untuk mengungkapkan hal-hal yang bersifat tidak konsisten dalam hubungannya dengan suatu laporan keuangan 
3. Dapat memberikan informasi yang diinginkan oleh para pengambil keputusan

4. Dapat digunakan untuk membandingkan dengan perusahaan lain atas dengan perusahaan lain secara industry

5. Untuk memahami situasi dan kondisi keuangan perusahaan

6. Dapat juga digunakan untuk memprediksi bagaimana keadaan perusahaan pada masa mendatang (proyeksi).

Berdasarkan penjelasan diatas dapat disimpulkan bahwa tujuan dan manfaat laporan keuangan adalah untuk memberikan informasi yang lebih mendalam terhadap laporan keuangan perusahaan, untuk memahami situasi dan kondisi keuangan perusahaan, serta untuk memprediksi bagaimana keadaan perusahaan pada masa mendatang.

\section{Rasio Keuangan}

Menurut Harahap (2015:297) rasio keuangan adalah angka yang diperoleh dari hasil perbandingan dari satu post laporan keuangan dengan post lainnya yang mempunyai hubungan yang relevan dan signifikan.

Sedangkan menurut Kasmir (2014:104) rasio keuangan merupakan kegiatan membandingkan angka-angka yang ada dalam laporan keuangan dengan cara membagi satu angka dengan angka lainnya. Perbandingan dapat dilakukan antara satu komponen dengan komponen dalam satu laporan keuangan atau antar komponen yang ada di antara laporan keuangan.

Agar dapat memberikan penilaian dan manfaat yang lebih jelas terhadap pengguna laporan keuangan serta memberikan struktur yang coherent dari beberapa rasio dan ukuran yang terlibat maka pembahasan akan dibangun dalam 3 sudut pandang utama yang kita ambil dalam analisis kinerja keuangan yaitu:

1. Pemilik (investor)

Ditinjau dari sudut pandang pemilik (investor) sebagai pengguna laporankeuangan, analisis rasio keuangan penting bagi pemilik (investor) salah satunya pada profitabilitas yaitu Return On Invesment (ROI).

2. Manajemen

Ditinjau dari sudut pandang manajemen sebagai pengguna laporan keuangan, analisis rasio keuangan diperlukan bagi manajemen sebagaialat analisis operasional dan profitabilitas. Analisis operasional diukur dengan 
gross profitmargin, net profit margin, operating income margin dan profitabilitas diukur dari Return on Total Asset (ROA).

3. Kreditur

Ditinjau dari sudut pandang kreditur analisis rasio keuangan diperlukan sebagai alat analisis likuiditas dan solvabilitas. Likuiditas diukur dari current ratio dan solvabilitas diukur dari debt to assets dan debt to equit.

\section{a. Rasio Likuiditas}

Menurut Martono (2011:53) rasio likuiditas adalah rasio yang menggambarkan kemampuan perusahaan dalam memenuhi kewajiban jangka pendeknya.

1. Current Ratio (Rasio Lancar)

$$
\text { Current Ratio }=\frac{\text { Current Asset }(\text { Aktiva Lancar })}{\text { Current Liabilities }(\text { Hutang Lancar })}
$$

Menurut Kasmir (2014:134) Rasio lancar (current ratio) merupakan rasio untuk mengukur kemampuan perusahaan membayar kewajiban jangka pendek atau utang yang segera jatuh tempo pada saat ditagih secara keseluruhan. Dengan kata lain, seberapa banyak aktiva lancar yang tersedia untuk menutupikewajiban jangka pendek yang segera jatuh tempo. Rasio lancar dapat pula dikatakan sebagai bentuk untuk mengukur tingkat keamanan (margin of safety) suatu perusahaan.

Sedangkan menurut Fahmi (2012) current ratio ( Rasio Lancar ) adalah ukuran yang umum digunakan atas solvensi jangka pendek, kemampuan suatu perusahaan memenuhi kebutuhan utang ketika jatuh tempo.

2. Quick Ratio (Rasio Cepat)

$$
\text { Quick Ratio }=\frac{(\text { Aktiva Lancar }- \text { Persediaan })}{\text { Utang Lancar }}
$$

Menurut Kasmir (2013:137) rasio cepat (quick ratio) adalah rasio cepat (quick ratio) merupakan rasio uji cepat yang menunjukkan kemampuan 
perusahaan membayar kewajiban jangka pendek dengan aktiva lancar tanpa memperhitungkan nilai sediaan (inventory).

Sedangkan menurut Hanafi dan Halim (2012:75) rasio cepat adalah perbandingan antara aktiva lancar yang dikurangi persediaan dengan utang lancarnya. Pada rasio ini jumlah inventory atau persediaan sebagai salah satu komponen dari aktiva lancar yang perlu dikeluarkan, sebab persediaan adalah komponen dari aktiva lancar yang paling tidak likuid, kemudian dengan quick ratio yaitu dimaksudkan untuk membandingkan aktiva yang lebih lancar.

Rasio ini digunakan untuk mengukur kemampuan perusahaan dalammemenuhi kewajiban jangka pendek, dengan asumsi bahwa semua aktiva lancar dikonversikan kedalam kas.

3. Cash Ratio (Rasio kas)

$$
\text { Cash } \text { Ratio }=\frac{(\text { Kas }+ \text { Surat Berharga })}{\text { Utang Lancar }}
$$

Menurut Kasmir (2012:138) cash ratio adalah alat yang dipergunakan untuk mengukur samapai seberapa besar uang kas yang tersedia untuk digunakan membayar hutang.

Menurut Sudana (2011:21) cash ratio adalah Cash ratio merupakan kemampuan kas dan surat berharga yang dimiliki perusahaan untuk menutup utang lancar.

Rasio kas (cash ratio) jarang digunakan oleh perusahaan karena kurang realistis dan tidak mudah dipertahankan nilainya. Jumlah kas berlebih yang ada pada perusahaan yang mampu menutupi kewajiban lancar sering dianggap sebagai kas tidak produktif yang tidak dimanfaatkan dengan baik.

\section{b. Rasio Solvabilitas}

Menurut Syamsuddin (2011:89) rasio solvabilitas adalah kemampuan perusahaan untuk menggunakan aktiva atau dana yang mempunyai beban tetap (fixed cost assets or funds) untuk memperbesar tingkat penghasilan (return) bagi pemilik perusahaan.

Sedangkan menurut Kasmir (2013:151) rasio solvabilitas adalah rasio yang digunakan untuk mengukur sejauh mana aktiva perusahaan dibiaya 
dengan hutang. Artinya berapa besar beban utang yang ditanggung perusahaan dibandingkan dengan aktivanya.

Adapun yang dikemukakan oleh Irham Fahmi (2014:59) bahwa rasio solvabilitas merupakan rasio yang menunjukkan bagaimana perusahaan mampu untuk mengelola hutangnya dalam rangka memperoleh keuntungan dan juga mampu untuk melunasi kembalihutangnya.

Debt to Asset Ratio (Debt Ratio)

Debt ratio menunjukkan seberapa besar total aset yang dimiliki perusahaan yang didanai oleh seluruh krediturnya. Semakin tinggi debt ratio akan menunjukkan semakin berisiko perusahaan karena semakin besar utang yang digunakan untuk pembelian asetnya.

Menurut Kasmir (2013:156) debt ratio adalah Debt ratio merupakan ratio yang digunakan untuk mengukur seberapa besar aktiva perusahaan dibiayai oleh utang atau seberapa besar utang perusahaan berpengaruh terhadap pengelolaan aktiva.

Sedangkan menurut Sudana (2011:20) debt ratio adalah debt ratio ini mengukur proporsi dana yang bersumber dari utang untuk membiayai aktiva perusahaan.

Perhitungan debt ratio adalah sebagai berikut:

$$
\text { Debt Ratio }=\frac{\text { Total Debt }}{\text { Total Asset }}
$$

\section{Debt to Equity Ratio}

Keputusan pendanaan perusahaan menyangkut keputusan tentang bentuk dan komposisi pendanaan yang akan dipergunakan oleh perusahan. Sumber pendanaan dapat diperoleh dari dalam perusahaan (internal financing) dan dari luar perusahaan (eksternal financing). Modal internal berasal dari laba ditahan, sedangkan modal eksternal dapet bersumber dari modal sendiri dan melalui hutang. Debt to Equity Ratio merupakan salah satu rasio leverage (solvabilitas) yang mengukur perbandingan antara modal eksternal dengan modal sendiri. 
Menurut Kasmir (2013:157) debt to equity ratio merupakan rasio yang digunakan untuk menilai utang dengan ekuitas. Untuk mencari rasio ini dengan cara membandingkan antara seluruh utang, termasuk utang lancar dengan seluruh ekuitas.

Sedangkan menurut Agus Sartono (2010:217) debt to equity ratio merupakan imbangan antara utang yang dimiliki perusahaan dengan modal sendiri. Semakin tinggi rasio ini berarti modal sendiri semakin sedikit dengan utangnya.

Perhitungan debt to equity ratio adalah sebagai berikut:

$$
\text { Debt to Equity Ratio }=\frac{\text { Total Liabilities }}{\text { Total Equitas }}
$$

> Long Term Debt to Equity Ratio

Menurut Kasmir (2013:159) long term debt to equity ratio adalah rasio antara utang jangka panjang dengan modal sendiri. Tujuannya adalah untuk mengukur berapa bagian dari setiap rupiah modal sendiri yang dijadikan jaminan utang jangka panjang dengan cara membandingkan antara utang jangka panjang dengan modal sendiri yang disediakan oleh perusahaan.

Perhitungan long term debt to equity ratio adalah sebagai berikut:

Long Term Debt to Equity Ratio $=\frac{\text { Long Term Debt }}{\text { Equity }}$

\section{c. Rasio Profitabilitas}

Menurut Kasmir (2016:196) rasio profitabilitas adalah rasio yang menilai kemampuan perusahaan dalam mencari keuntungan.

Sedangkan menurut Fahmi (2017:135) rasio profitabilitas adalah rasio yang mengukur efektivitas manajemen secara keseluruhan yang ditujukan oleh besar kecilnya tingkat keuntungan yang diperoleh dalam hubungannya dengan penjualan maupun investasi. Semakin baik rasio profitabilitas maka semakin baik menggambarkan kemampuan tingginya perolehan keuntungan perusahaan. 
Net Profit Margin (NPM)

Menurut Kasmir (2012:200) NPM merupakan rasio yang digunakan untuk mengukur margin laba atas penjualan, rasio ini akan menggambarkan penghasilan bersih perusahaan berdasarkan total penjualan.

Sedangkan menurut Syamsudin (2011:62) NPM merupakan rasio antara laba bersih (net profit) yaitu penjualan sesudah dikurangi dengan seluruh expenses termasuk pajak dibandingkan dengan penjualan. Semakin tinggi net profit margin semakin baik operasi suatu perusahaan. Suatunet profit margin yang dikatakan "baik" akan sangat tergantung dari jenis industri di dalam dimana perusahaan itu berusaha.

Perhitungan Net Profit Margin sebagai berikut:

Net Profit Margin Ratio $=\frac{\text { Laba Bersih }}{\text { Total Pendapatan }} \times 100 \%$

Return On Assets (ROA)

Dalam kegiatan suatu perusahaan, perusahaan tentu menginginkan profit yang optimal. Oleh karena itu perusahaan melakukan berbagai upaya untuk memperoleh itu, namun untuk mengetahui perusahaan memperoleh profit yang optimal perlu dilakukan suatu alat ukur perusahaan. Dengan ROA dalam rasio profitabilitas adalah untuk megukur sejauh mana seluruh aset perusahaan yang digunakan dalam menghasilkan laba perusahaan.

Menurut Sartono (2010:123) Return On Assets adalah menunjukkan kemampuan perusahaan menghasilkan laba dari aktiva yang dipergunakan.

Sedangkan menurut Syamsudin (2011:63) Return On Assets (ROA) merupakan pengukuran kemampuan perusahaan secara keseluruhan di dalam menghasilkan keuntungan dengan jumlah keseluruhan aktiva yang tersedia di dalam perusahaan. Semakin tinggi rasio ini, semakin baik keadaan suatu perusahaan.

Perhitungan Return On Asset sebagai berikut:

Return On Asset $=$ Net Profit Margin $\times$ The Degree of Asset Utilization 
atau

$$
\text { Return On Asset }=\frac{\text { Laba Tahun Baejalan }}{\text { Total Asset }} \times 100 \%
$$

Return On Equity (ROE)

Dalam kegiatan suatu perusahaan, perusahaan tentu menginginkan profit yang optimal. Oleh karena itu perusahaan melakukan berbagai upaya untuk memperoleh itu demi mensejahterahkan para investor, namun untuk mengetahui perusahaan memperoleh profit yang optimal perlu dilakukan suatu alat ukur perusahaan. Dengan ROE dalam rasio profitabilitas adalah untuk megukur sejauh mana perusahaan dalam melakukan aktivitasnya menghasilkan laba dalam bentuk keuntungan laba dari saham yang ditanam.

Menurut Sartono (2010:124) Return On Equity adalah mengukur kemampuan perusahaan memperoleh laba yang tersedia bagi pemegang saham perusahaan.

Sedangkan menurut Syamsudsin (2011:64) ROE adalah suatu pengukuran dari penghasilan (income) yang tersedia bagi para pemilik perusahaan (baik pemegang saham biasa maupun pemegang saham preferen) atas modal yang mereka investasikan di dalam perusahaan. Secara umum tentu saja semakn tinggi return atau penghasilan yang diperoleh semkain baik kedudukan pemilik perusahaan.

Perhitungan Return On Equity sebagai berikut:

$$
\text { Return On Equity }(\text { ROE })=\frac{\text { Laba Bersih }}{\text { Ekuitas }} \times 100 \%
$$

\section{d. Rasio Aktivitas}

Rasio aktivitas adalah rasio yang mengukur seberapa efektif perusahaan dalam memanfaatkan semua sumber daya yang ada padanya. Semua rasio aktivitas ini melibatkan perbandingan antara tingkat penjualan dan investasi pada berbagai jenis aktiva. Rasio-rasio aktivitas menganggap 
bahwa sebaiknya terdapat keseimbangan yang layak antara penjualan dan beragam unsur aktiva misalnya persediaan, aktiva tetap dan aktiva lainnya.

Menurut Kasmir (2017 : 172) rasio aktivitas adalah rasio yang digunakan untuk mengukur efektivitas perusahaan dalam menggunakan aktiva yang dimilikinya. Atau dapat pula dikatakan rasio ini digunakan untuk mengukur tingkat efesiensi (efektivitas) pemanfaatan sumber daya perusahaan.

Perputaran Aktiva (Total Assets Turnover)

Menurut Kasmir (2017:185) Total assets turn over merupakan rasio yang digunakan untuk mengukur perputaran semua aktiva yang dimiliki perusahaan dan mengukur berapa jumlah penjualan yang diperoleh dari tiap rupiah aktiva.Jadi semakin besar rasio ini semakin baik yang berarti bahwa aktiva dapat lebih cepat berputar dan meraih laba dan menunjukan semakin efisien penggunaan keseluruhan aktiva dalam menghasilkan penjualan. Dengan kata lain jumlah asset yang sama dapat memperbesar volume penjualan apabila assets turnovernya ditingkatkan atau diperbesar.Total assets turnoverpenting bagi para kreditur dan pemilik perusahaan, tapi akan lebih penting lagi bagi manajemen perusahaan, karena hal ini akan menunjukan efisien tidaknya penggunaan seluruh aktiva dalam perusahaan.Dihitung dengan membagi antara penjualan dengan total assetnya.

Total assets turn over dihitung sebagai berikut:

Total Asset Turn Over $=\frac{\text { Penjualan }}{\text { Total Aktiva }}$

\section{> Perputaran Modal Kerja (Working Capital Turn over)}

Menurut Kasmir (2017:182) perputaran modal kerja adalah rasio yang mengukur atau menilai keefektifan modal kerja perusahaan selama periode tertentu. Artinya seberapa banyak modal kerja berputar selama suatu periode atau dalam suatu periode. Untuk mengukur rasio ini, kita membandingkan antara penjualan dengan modal kerja atau dengan modal kerja rata-rata. 
Dari hasi penilaian, apabila perputaran modal kerja yang rendah, dapat diartikan perusahaan sedang kelebihan modal kerja. Hal ini mungkin disebabkan karena rendahnya perputaran persediaan atau piutang atau saldo kas yang terlalu besar. Demikian pula sebaliknya jika perputaran modal kerja tinggi, mungkin disebabkan tingginya perputaran persediaan atau perputaran piutang aatau saldo kas yang terlalu kecil.

Rumus yang digunakan untuk mencari perputaran modal kerja adalah sebagai berikut:

$$
\begin{aligned}
& \text { Perputaran Modal Kerja }=\frac{\text { Penjualan }}{\begin{array}{c}
\text { Modal Kerja } \\
\text { Pejualan }
\end{array}} \\
& =\frac{(\text { Aktiva Lancar - Utang Lancar })}{\text { Len }}
\end{aligned}
$$

\section{Penelitian Terdahulu}

Penelitian ini mengacu pada penelitian yang pernah dilakukan oleh beberapa peneliti terdahulu, yaitu:

a) Tiroima (2020), melakukan penelitian tentang : "Dampak Pandemi Covid19 Terhadap Kondisi dan Kinerja Fungsi Maritime Training Center PT. Pertamina Persero." Hasil penelitian menujukkan bahwa PMTC mengalami penurunan pendapatan yang signifikan, baik pada cabang Jakarta maupun Batam. Hal ini dikarenakan adanya realokasi anggaran yang diberikan kepada perusahaan. Selain karena situasi pandemic COVID-19, realokasi anggaran perusahaan ini terpaksa dilakukan karena terjadinya kerugian pada PT. Pertamina Persero akibat turunnya harga minyak secara signifikan. Oleh karena itu, PMTC terpaksa harus menutup program pelatihan yang bersifat teknis dan jumlah peserta yang mendaftar.

b) Safitri, dkk (2020), melakukan penelitian tentang : "Gotong Royong Menghadapi Pandemi Covid-19." Hasil penelitian menunjukkan bahwa masa teror dari pandemic Covid-19 yang terus menghantui dan menelan banyak korban jiwa dan korban yang dirawat, maka salah satu cara yang dapat dilakukan oleh pemerintah dan harus dilakukan oleh seluruh pegawai baik pegawai pemerintahan maupun swasta adalah melaksanakan Work From Homedengan disiplin dan berkomitmen. 
c) Pillar (2012) melakukan penelitian tentang : "Evaluasi Sistem Pengendalian Intern Penjualan Kredit." Hasil penelitian menunjukkan bahwa efektifitas pengendalian intern pada sistem penjualan kredit PT. Trakindo Utama masih dijumpai adanya kelemahan yang perlu diperbaiki oleh perusahaan. Hasil dari pengujian pengendalian yang telah dilakukan dengan menggunakan dua metode yaitu stop or go sampling karena perkiraan awal peneliti bahwa pelaksanaan sistem pengendalian intern penjualan kredit PT. Trakindo Utama sudah baik.

\section{METODE PENELITIAN}

\section{A. Lokasi dan Waktu Penelitian}

Penelitian ini dilaksanakan pada kantor PT Trakindo Utama, Tembagapura Division yang berlokasi di Jl. Kuala Kencana, Kec. Kuala Kencana, Timika, Papua dan waktu penelitian kurang lebih 1 (satu) bulan.

\section{B. Sumber dan Jenis Data}

\section{Sumber Data}

Jenis data yang digunakan dalam penelitian ini adalah data kuantitatif, yaitu data laporan keuangan PT Trakindo Utama cabang, Tembagapura Division tahun 2019-2020.

\section{Jenis data}

Dalam penelitian ini, data yang digunakan bersumber dari data sekunder berupa data keuangan yang kuantitatif dan juga diperoleh dari beberapa jurnal pendukung yang berkaitan dengan judul penulis serta referensi-referensi lainnya.

\section{Teknik Pengumpulan Data}

Penelitian kepustakaan (Library Research) yaitu penelitian yang dilakukan dengan mengumpulkan data-data dari buku-buku, literatur, artikel, jurnal ilmiah dan bahan analisis yang berkaitan dengan penelitian.

Penelitian dokumentasi yaitu data dari laporan keuangan yang dikeluarkan oleh PT Trakindo Utama, Tembagapura Division. Data yang dikumpulkan tersebut berupa laporan keuangan perusahaan untuk periode satu tahun terakhir yaitu tahun 2019 sampai tahun 2020. 


\section{Populasi dan Sampel}

\section{Populasi}

Populasi yang digunakan dalam penelitian ini adalah laporan keuangan pada PT Trakindo Utama, Tembagapura Division tahun 2019-2020.

\section{Sampel}

Sampel dalam peneletiaan ini ini adalah sampel jenuh yaitu laporan keuangan PT Trakindo Utama, Tembagapura Division tahun 2019-2020.

\section{E. Definisi Opersional}

Kinerja Keuangan merupakan suatu tingkat keberhasilan yang dicapai suatu perusahaan dalam mengelola keuangan yang dimiliki perusahaan, dimana dalam melakukan pengukuran kinerja keuangan dapat dilakukan dengan beberapa rasio keuangan, diantaranya sebagai berikut:

a. Rasio Likuiditas adalah rasio untuk mengukur kemampuan perusahaan dalam memenuhi kewajiban jangka pendek

b. Rasio Solvabilitas adalah rasio ini digunakan untuk mengukur kemampuan perusahaan untuk membayar seluruh kewajibannya, baik jangka pendek maupun jangka panjang apabila perusahaan dibubarkan.

C. Rasio Profitabilitas adalah rasio yang dilakukan untuk mengukur kemampuan perusahaan dalam memperoleh keuntungan dalam suatu periode tertentu atau beberapa periode.

d. Rasio aktivitas merupakan rasio yang digunakan untuk mengukur efektivitas perusahaan dalam menggunakan aktiva yang dimilikinya.

\section{F. Analisis data}

1. Rasio Likuiditas adalah rasio untuk mengukur kemampuan perusahaan dalam memenuhi kewajiban jangka pendek. Yang dapat diukur:

a. Rasio Lancar (Current Ratio)

$$
\text { Rasio Lancar }=\frac{\text { aktiva lancar }}{\text { hutang lancar }}
$$

b. Rasio Cepat (Quick Ratio)

$$
\text { Rasio Cepat }=\frac{\text { asset lancar }- \text { persediaan }}{\text { utang lancar }}
$$


2. Rasio Solvabilitas adalah rasio ini digunakan untuk mengukur kemampuan perusahaan untuk membayar seluruh kewajibannya, baik jangka pendek maupun jangka panjang apabila perusahaan dibubarkan. yaitu :

a. Debt Ratio

$$
\text { Debt ratio }=\frac{\text { total hutang }}{\text { total aktiva }}
$$

b. Debt to Equity Ratio (DER)

$$
\text { debt to equity }=\frac{\text { total hutang }}{\text { ekuitas }}
$$

3. Rasio Profitabilitas adalah rasio yang dilakukan untuk mengukur kemampuan perusahaan dalam memperoleh keuntungan dalam suatu periode tertentu atau beberapa periode. Yang dapat diukur:

a. Return on Investmant (ROI)

$$
R O I=\frac{\text { laba sesudah bunga dan pajak }}{\text { total aktiva }}
$$

b. Return on Equity

$$
R O E=\frac{\text { laba sesudah bunga dan pajak }}{\text { total equitas }}
$$

4. Rasio aktivitas merupakan rasio yang digunakan untuk mengukur efektivitas perusahaan dalam menggunakan aktiva yang dimilikinya. Rasio diukur dengan dua rasio yaitu :

a. Perputaran Piutang (Receivable Turn Over)

$$
\text { Perputaran piutang }=\frac{\text { penjualan } k r e d i t}{\text { rata }- \text { rata piutang }}
$$

b. Perputaran Persediaan (Inventory Turn Over)

$$
\text { Perputaran persediaan }=\frac{\text { harga pokok penjualan }}{\text { rata }- \text { rata persediaan }}
$$

\section{KESIMPULAN}

Berdasarkan hasil analisis data dari sejumlah data yang dihimpun, maka dapat ditarik kesimpulan sebagai berikut :

1. Rasio Likuiditas menunjukkan kemampuan PT Trakindo Utama, Tembagapura Division untuk memenuhi kewajiban atau utang jangka pendek yang diwakili : Current Rasio, Cash Rasio, Quick Rasio. 
2. Rasio solvabilitas menggambarkan tentang seberapa besar kebutuhan PT Trakindo Utama, Tembgapura Division yang dibiayai oleh utang yang diwakili: Debt to Assets Rasio, Debt to Equity Rasio, Long Term Debt to Equity Rasio, Times Interest Earned.

3. Rasio profitabilitas digunakan untuk mengukur kemampuan PT Trakindo Utama, Tembagapura Division untuk menghasilkan laba dari pendapatan yang berhubungan dengan penjualan, aset, dan ekuitas yang diwakili : Net Profit Margin, Gross Profit Margin, Return On Asset (ROA), Return On Equity (ROE).

4. Rasio aktivitas mengukur seberapa efektif PT Trakindo Utama, Tembagapura Division dalam memanfaatkan semua sumber daya yang ada dengan mewakili : Inventory Turn Over, Fixed Asset Turn Over dan Total Asset Turn Over. 


\section{DAFTAR PUSTAKA}

Daga, R. (2021). Faktor-Faktor Yang Mempengaruhi Loyalitas Karyawan Pada Pt. Bank Syariah Mandiri Kantor Cabang Makassar.

Kani, B. R., Mandagi, R. J., p Rantung, J., \& Malingkas, G. Y. (2013). Keselamatan Dan Kesehatan Kerja Pada Pelaksanaan Proyek Konstruksi (Studi Kasus: Proyek Pt. Trakindo Utama). Jurnal Sipil Statik, 1(6).

Mentang, M. I. F., Tjakra, J., Langi, J. E. C., \& Walangitan, D. R. O. (2013). Evaluasi penerapan sistem manajemen keselamatan dan kesehatan kerja pada peningkatan fasilitas PT. Trakindo Utama Balikpapan. Jurnal Sipil Statik, 1(5).

Utama, A. G. S., \& Prabiyanto, A. E. (2019). E-Procurement System Pengadaan Barang Dan Jasa Pada Pt. Trakindo Utama Surabaya. Jurnal Riset Akuntansi Dan Bisnis Airlangga, 4(1).

Qurbani, D., \& Selviyana, U. (2018). PENGARUH KESELAMATAN \& KESEHATAN KERJA (K3) TERHADAP KINERJA KARYAWAN PADA PT. TRAKINDO UTAMA CABANG BSD. Jimf (Jurnal Ilmiah Manajemen Forkamma), 1(3). 